\title{
Infusing a Course-Based Undergraduate Research Experience (CURE) into an Allied Health Curriculum
}

\author{
Deborah A. Johnson \\ Illinois State University, dajohn5@ilstu.edu \\ Beverly J. Barham \\ Illinois State University, bjbarha@ilstu.edu \\ Susan R. Franzen \\ Illinois State University, srfranz@ilstu.edu
}

Follow this and additional works at: https://nsuworks.nova.edu/ijahsp

Part of the Higher Education Commons, and the Medicine and Health Sciences Commons

\section{Recommended Citation}

Johnson DA, Barham BJ, Franzen SR. Infusing a Course-Based Undergraduate Research Experience (CURE) into an Allied Health Curriculum. The Internet Journal of Allied Health Sciences and Practice. 2021 Jan 01;19(1), Article 5.

This Manuscript is brought to you for free and open access by the College of Health Care Sciences at NSUWorks. It has been accepted for inclusion in Internet Journal of Allied Health Sciences and Practice by an authorized editor of NSUWorks. For more information, please contact nsuworks@nova.edu. 


\title{
Infusing a Course-Based Undergraduate Research Experience (CURE) into an Allied Health Curriculum
}

\begin{abstract}
Purpose: Infusion of a course-based undergraduate research experience (CURE) into an existing research design course in an applied science curriculum allowed medical laboratory science students $(n=22)$ to each be a contributing team member in a hand's-on research experience, where most of the work was completed during the class time on campus. This design allowed for equal access, an equitable experience, and inclusion of all students enrolled in the course. Methods: Students and instructors worked together to develop a research question. The group agreed that the research question would be to determine the number of environmental specimens that were positive for mycobacteria species in residential plumbing specimens from different faucets and showerheads within residences in local areas. Before the actual collection of specimens, students reviewed the literature and completed more traditional modules in research ethics and Collaborative Institutional Training Initiative (CITI) training. Once that was completed, students designed and assembled the collection kits, collected and processed the specimens, and reported their results. Results: Students completed most tasks during the designated class time, and those tasks that had to be completed outside of class were not overwhelming for the students either in time or effort. The students' reflections as the human subjects in this CURE indicated that 1) $90 \%$ of the students agreed they had a better understanding of the Institutional Review Board (IRB) process, 2) 100\% of the students agreed the collection process was easily completed, 3) $100 \%$ of the students agreed the specimen testing was easily completed and interpreted, and 4) $100 \%$ of the students agreed the required parameters of a CURE were met. Conclusion: A CURE can be infused successfully into an applied science course allowing every student to become a contributing member of the research team.
\end{abstract}

\section{Author Bio(s)}

Deborah A. Johnson, M.S., MT(ASCP), SM, is an Assistant Professor in the Medical Laboratory Science Program at Illinois State University. She has 30 years of experience as a certified Medical Technologist with the last three years working as an educator in the program at Illinois State University.

Beverly J. Barham, PhD, MPH, MT(ASCP) is a Professor in the Medical Laboratory Science Program at Illinois State University. She has over forty years of experience as a certified Medical Technologist with the last twenty of those years working as an educator in the program at Illinois State University.

Susan R. Franzen, MLIS, MS is an Assistant Professor in Milner Library at Illinois State University. She currently serves as library liaison to the Department of Health Sciences and Mennonite College of Nursing. Susan was formerly a composition instructor at Illinois State University as well as a public library director. 


\title{
TIAHSP \\ The Internet Journal of Allied Health Sciences and Practice
}

Dedicated to allied health professional practice and education

Vol. 19 No. 1 ISSN 1540-580X

\section{Infusing a Course-Based Undergraduate Research Experience (CURE) into an Allied Health Curriculum}

\author{
Deborah A. Johnson \\ Beverly J. Barham \\ Susan R. Franzen \\ Illinois State University \\ United States
}

\begin{abstract}
Purpose: Infusion of a course-based undergraduate research experience (CURE) into an existing research design course in an applied science curriculum allowed medical laboratory science students $(n=22)$ to each be a contributing team member in a hand'son research experience, where most of the work was completed during the class time on campus. This design allowed for equal access, an equitable experience, and inclusion of all students enrolled in the course. Methods: Students and instructors worked together to develop a research question. The group agreed that the research question would be to determine the number of environmental specimens that were positive for mycobacteria species in residential plumbing specimens from different faucets and showerheads within residences in local areas. Before the actual collection of specimens, students reviewed the literature and completed more traditional modules in research ethics and Collaborative Institutional Training Initiative (CITI) training. Once that was completed, students designed and assembled the collection kits, collected and processed the specimens, and reported their results. Results: Students completed most tasks during the designated class time, and those tasks that had to be completed outside of class were not overwhelming for the students either in time or effort. The students' reflections as the human subjects in this CURE indicated that 1) $90 \%$ of the students agreed they had a better understanding of the Institutional Review Board (IRB) process, 2) $100 \%$ of the students agreed the collection process was easily completed, 3) $100 \%$ of the students agreed the specimen testing was easily completed and interpreted, and 4) $100 \%$ of the students agreed the required parameters of a CURE were met. Conclusion: A CURE can be infused successfully into an applied science course allowing every student to become a contributing member of the research team.
\end{abstract}

Keywords: course-based research, inclusion 


\section{INTRODUCTION}

Infusing a course-based undergraduate research experience (CURE) into a basic science course is not a new concept in course design. When reviewing the literature, it is clear there are many instructors who have been successful in designing a CURE to be infused into existing courses or as a stand-alone course predominantly in the area of the basic sciences, most often in the biological sciences. ${ }^{1,2}$ Infusing a CURE into the applied sciences presents some challenges, in that the courses in the applied science curricula often have very tight parameters on content to be mastered and the timeline to accomplish those goals. Infusing a CURE into an already existing course does have challenges but the advantages of having students participate in the experience and learn first-hand, far outweighs the added work required for the instructors to make this all happen in one semester. It was our goal to give all the medical laboratory science (MLS) student cohort $(n=22)$, the opportunity to be a contributing member of a research team in a setting that offered equal access, an equitable experience, and included the entire cohort.

The MLS curriculum is a rigorous program that prepares students to become practicing professionals with transferable skill sets that will allow them to be employed not only in hospital or clinical settings, but in basic science research facilities, forensic labs, government laboratories and business entities with product research and development laboratories. Many times, MLS students wear multiple hats in their lives outside of academe such as family and work responsibilities or they may have a lengthy commute to campus daily. These added responsibilities take a significant amount of time and often prevent students from investigating opportunities in research labs on campus. In order to do a better job preparing students for future employment opportunities, a CURE was infused into a required course allowing students to be part of a research team while enrolled in the course.

Educators who have considerable experience in CURE have agreed on 5 parameters for the experience to be considered a CURE. Those include 1) use of multiple scientific practices 2) the outcome is unknown 3) there is a broader relevance or importance beyond this classroom experience 4) collaboration is essential among students and instructors, 5) iteration is built into the process. 1,3 This CURE model was designed to be infused into a required research design course during the fall semester of 2019. Students took on the role of both environmental researchers and as human subjects when they were asked to give their reflections on the experience at different times throughout the semester. To meet the requirements of the Institutional Review Board (IRB), the document was written to be inclusive for both the student researcher role and the student role as human subjects in this CURE. Before the CURE was launched in the course, students were given the more traditional content on types of research design, ethics training, and data analysis strategies. Students were required to complete the CITI training modules for "students with minimal risk research" so they would have a better understanding about the differences between basic science research and human subjects research. The goal was to provide a solid background in research design content before they took on the two different roles in the CURE.

When CUREs are implemented into courses, they can originate from different ideas. CUREs can be adapted from a preestablished CURE, or designed to create an experience that targets a specific learning goal, or they can be developed and molded from a faculty's research agenda. ${ }^{4}$ Examples of some pre-established CUREs include the Genomics Education Partnership and the Prevalence of Antibiotic Resistance in the Environment (PARE).3,5

Participating in a CURE may reduce the stress associated with balancing an additional research opportunity and daily course work. CUREs can offer different types of opportunities to develop ownership of projects. ${ }^{1}$ Studies have shown that CUREs increase student performance, retention, self-reported learning, and the ability to "think like a scientist".,6-9 There are multiple confirmed student outcomes from CUREs. These outcomes can range from direct course-related outcomes (increased knowledge, increased analytical skills, and increased technical skills) to personal and career-related achievements (increased self-efficacy, external validation, persistence in science, and career clarification).4,10 One study found that students who had been part of a CURE during the early years of college produced targeted knowledge gains that lasted into the senior year. ${ }^{11}$

\section{METHODS}

All expectations of the course were clearly defined in the syllabus and then again on the first day of class. The CURE experience was infused into existing course content about halfway through the 16-week semester. Background areas including research design content (i.e.: various types of research, ethics training, review of literature techniques, along with data collection and analysis) were delivered through discussions, course assignments, on-line library assignments designed specifically for these students, and group work before the CURE portion began.

Once the students had completed the assignments in the background areas, the CURE objectives became the focus. As a requirement of the course, students earned points for completing the objectives outlined in the CURE format. Those objectives included developing a research question as a group, creating a review of literature working in specific groups, collecting specimens, testing the specimens, analyzing the test results, and reflecting on their various experiences throughout the CURE. 


\section{Students as Human Subjects}

Students became the human subjects of this work when they were asked to fill out anonymous surveys reflecting on their experiences in the different areas within the CURE and then decide to allow or not allow their reflections to be shared by signing an informed consent letter. This work was overseen by the IRB and required that a faculty member other than the instructor of record, be the designated person to gather the consent forms and analyze the data from the student reflections. This data was stored in a locked cabinet in the office of that faculty member. Students were required to take this course as part of the MLS curriculum and to participate in the CURE experience as a requirement of the course, but they could decline to have their data shared with no penalty and without the instructor of record knowing that decision.

\section{Students as Environmental Researchers}

The students and the instructor agreed that the research question would be to determine the number of specimens that were positive for opportunistic mycobacteria species present as an opportunistic plumbing pathogen in residential plumbing from various residences. Students were tasked with the design and assembly of the collection kits. After collection, the specimens were processed with a fluorescent stain. Results of the staining determined if the specimens were positive or negative by comparing the stained specimens to a positive and negative control on each slide. All quality control guidelines and universal precautions were followed. The staining results were documented, and the percentage of positive specimens was determined.

\section{RESULTS}

\section{Human Subject Data}

As the human subjects in this research, the students completed surveys on each step of the research process. Topics included reflections for the IRB process, collection process, fluorescent staining and analysis, and meeting the overall parameters of a CURE. The student responses from the surveys can be seen in Tables 1-4.

Table 1: Reflections on Research Ethics

\begin{tabular}{|l|c|c|c|c|c|}
\hline $\begin{array}{l}\text { Institutional Review Board Process } \\
\text { Reflection }\end{array}$ & $\begin{array}{c}\text { Strongly } \\
\text { Disagree }\end{array}$ & Disagree & $\begin{array}{c}\text { Neither } \\
\text { Agree nor } \\
\text { Disagree }\end{array}$ & Agree & $\begin{array}{c}\text { Strongly } \\
\text { Agree }\end{array}$ \\
\hline $\begin{array}{l}\text { I have a better understanding of } \\
\text { research ethics and who oversees the } \\
\text { process. }\end{array}$ & $0 \%$ & $0 \%$ & $5 \%$ & $50 \%$ & $45 \%$ \\
\hline $\begin{array}{l}\text { I have a better understanding of the } \\
\text { Three Ethical Principles discussed in } \\
\text { the Belmont Report. (Respect for } \\
\text { persons, Beneficence, and Justice) }\end{array}$ & $0 \%$ & $0 \%$ & $0 \%$ & $59 \%$ & $41 \%$ \\
\hline $\begin{array}{l}\text { I have a better understanding about } \\
\text { the role of the Institute Review Board } \\
\text { (IRB). }\end{array}$ & $0 \%$ & $5 \%$ & $5 \%$ & $36 \%$ & $54 \%$ \\
\hline
\end{tabular}

The first statement addressed student reflections about having a better understanding of research ethics. One student response was neutral (neither agree nor disagree) but all other student responses either agreed or strongly agreed. The second statement addressed student reflections in having a better understanding of the Belmont Report. All students agreed or strongly agreed with this statement. The third statement addressed the IRB and its' role in research. One student response disagreed that they now had a better understanding of the role of the IRB and one student response was neutral (neither agree nor disagree), but all other student responses either agreed or strongly agreed with this statement.

Table 2. Reflections on the Collection Process

\begin{tabular}{|l|c|c|c|c|c|}
\hline $\begin{array}{l}\text { Collection Process and Data } \\
\text { Collection Reflection }\end{array}$ & $\begin{array}{c}\text { Strongly } \\
\text { Disagree }\end{array}$ & Disagree & $\begin{array}{c}\text { Neither } \\
\text { Agree nor } \\
\text { Disagree }\end{array}$ & Agree & $\begin{array}{c}\text { Strongly } \\
\text { Agree }\end{array}$ \\
\hline $\begin{array}{l}\text { I was able to access collection sites } \\
\text { easily. }\end{array}$ & $0 \%$ & $0 \%$ & $0 \%$ & $14 \%$ & $86 \%$ \\
\hline $\begin{array}{l}\text { Time spent on specimen collection } \\
\text { was minimal. }\end{array}$ & $0 \%$ & $0 \%$ & $0 \%$ & $14 \%$ & $86 \%$ \\
\hline
\end{tabular}




\begin{tabular}{|l|c|c|c|c|c|}
\hline $\begin{array}{l}\text { Specimen data collection sheet was } \\
\text { clear and concise }\end{array}$ & $0 \%$ & $0 \%$ & $0 \%$ & $27 \%$ & $73 \%$ \\
\hline $\begin{array}{l}\text { Overall, the specimen collection } \\
\text { process and data reporting were } \\
\text { efficient. }\end{array}$ & $0 \%$ & $0 \%$ & $0 \%$ & $14 \%$ & $86 \%$ \\
\hline
\end{tabular}

Table 3. Reflections on the Staining Process

\begin{tabular}{|l|c|c|c|c|c|}
\hline $\begin{array}{l}\text { Modified Auramine O Fluorescent } \\
\text { Stain Reflection }\end{array}$ & $\begin{array}{c}\text { Strongly } \\
\text { Disagree }\end{array}$ & Disagree & $\begin{array}{c}\text { Neither } \\
\text { Agree nor } \\
\text { Disagree }\end{array}$ & Agree & $\begin{array}{c}\text { Strongly } \\
\text { Agree }\end{array}$ \\
\hline $\begin{array}{l}\text { Preparing slides and performing the } \\
\text { Modified Auramine O stain was } \\
\text { completed efficiently. }\end{array}$ & $0 \%$ & $0 \%$ & $0 \%$ & $14 \%$ & $86 \%$ \\
\hline $\begin{array}{l}\text { Reading and interpreting the } \\
\text { fluorescent stain was explained } \\
\text { clearly. }\end{array}$ & $0 \%$ & $0 \%$ & $0 \%$ & $27 \%$ & $73 \%$ \\
\hline $\begin{array}{l}\text { Reporting the results of Mycobacteria } \\
\text { species present or not present was } \\
\text { explained clearly. }\end{array}$ & $0 \%$ & $0 \%$ & $0 \%$ & $14 \%$ & $86 \%$ \\
\hline $\begin{array}{l}\text { Overall, the Modified Auramine O } \\
\text { fluorescent stain procedure was an } \\
\text { efficient process. }\end{array}$ & $0 \%$ & $0 \%$ & $0 \%$ & $14 \%$ & $86 \%$ \\
\hline
\end{tabular}

Table 4. Reflections on the Overall CURE

\begin{tabular}{|l|c|c|c|c|c|}
\hline $\begin{array}{l}\text { Overall Reflection on the CURE } \\
\text { Process }\end{array}$ & $\begin{array}{c}\text { Strongly } \\
\text { Disagree }\end{array}$ & Disagree & $\begin{array}{c}\text { Neither } \\
\text { Agree nor } \\
\text { Disagree }\end{array}$ & Agree & $\begin{array}{c}\text { Strongly } \\
\text { Agree }\end{array}$ \\
\hline $\begin{array}{l}\text { This process has helped me have a } \\
\text { better understanding of research } \\
\text { design. }\end{array}$ & $0 \%$ & $0 \%$ & $0 \%$ & $27 \%$ & $73 \%$ \\
\hline $\begin{array}{l}\text { This process has helped me } \\
\text { understand data collection } \\
\text { requirements. }\end{array}$ & $0 \%$ & $0 \%$ & $0 \%$ & $18 \%$ & $82 \%$ \\
\hline $\begin{array}{l}\text { Overall, this experience has helped me } \\
\text { understand the intent of infusing the } \\
\text { course based undergraduate research } \\
\text { experience (CURE) process into the } \\
\text { MLS curriculum. }\end{array}$ & $0 \%$ & $0 \%$ & $0 \%$ & $23 \%$ & $77 \%$ \\
\hline
\end{tabular}

\section{DISCUSSION}

The results of this CURE are consistent with data from other educators who use CURE in their courses. ${ }^{1}$ There has been a concerted effort to include authentic research practices within science, technology, engineering, and mathematic courses across various disciplines and educational levels.4,6,12,13 Research experiences are particularly beneficial for first-generation students, underrepresented minorities, at-risk students, and women.1,3

In this CURE, the students were considered the human subjects when they reflected on their experiences as members of the CURE team. Student reflection surveys were completed as a self-assessment and were anonymous. Students filled out paper surveys for four different experiences. All surveys included multiple statements regarding each experience. In accordance with the IRB guidelines, the faculty member who was not the instructor of record collected all student reflections and analyzed the data. Using self-assessments with reflective statements was efficient for both students and faculty. The results indicated that each part of this CURE was a positive experience for students. There were responses to two different statements regarding research ethics that were either neutral or disagreed with the statement, but those were the only two statements where $100 \%$ of the students did 
not agree or strongly agree with each statement. This data was encouraging for the two faculty members and no doubt will be an important factor in future decisions to infuse a CURE into this course on a regular basis.

\section{Limitations of Infusing CURE into an Existing Course}

Even though the literature from multiple sources supports the positive outcomes of CUREs, there are still challenges and limitations when infusing a CURE into an existing course. The biggest challenge of CUREs is the time and energy required for the CURE design and implementation. ${ }^{4,8}$ Remodeling the course content to make a seamless transition for the CURE is time consuming particularly when trying to balance this with other responsibilities as full time faculty members.

One limitation with this CURE was the low number of specimens in the sample size. Future CUREs may include students collecting more specimens for a larger sample size. Another design option would be to have a parallel testing format where two different testing methodologies are used on each sample and the results of those two testing methodologies are then compared. This is a very common practice in the clinical laboratory when a new test format is being implemented. The current method continues to be used to generate patient data, but those same patient specimens are also analyzed using the new method. The results of the two methods are then compared and decisions are made once that comparison data has been analyzed. This would give the students an experience using multiple testing methods and allow them to see how the two different sets of data are used in making a conclusion.

Another limitation for this CURE was the number of minutes in each class time. A fifty-minute class time was minimal when the majority of work was to be done in class. Creative scheduling and time on task became very important. Future plans include moving the actual testing process to a one hour and fifty-minute laboratory session in another required MLS course with the same cohort of students. The hand's-on content will be a good fit for the laboratory session in the other course. The background content and all the data analysis will still be included in the fifty-minute research design course.

\section{CONCLUSION}

A complete course-based undergraduate experience (CURE) can be infused into an existing semester long course in an applied science curriculum with positive outcomes for both the student and the instructor. Careful planning in course design is of paramount importance. A solid background in research design content needs to be completed before the students begin the actual CURE portion of the course. The applied sciences often have very heavy content courses, each meeting the requirements for subsequent certification of the student as a professional in the specific field upon graduation. The solution to identifying a course that will accommodate the infusion of a CURE is to identify a course where the CURE can help deliver existing content

through the hand's-on experience providing an enhanced student experience.

From the instructor perspective, the fact that all students were involved in the entire experience from beginning to end, was a powerful motivator to consider future infusions of other CUREs in this course. Students engaged in sharing ideas and working as a cohesive laboratory team. This CURE allowed students to know what it feels like to be a contributing member of a team. It allowed the students to see how discussion is a good way to work through a research question. Students were able to use their clinical laboratory skills and apply them when testing the environmental specimens which expanded their scope of practice. The fact that no one knew the results ahead of time, gave the students a sense of empowerment. Having the students reflect on their experiences, provided the human subjects perspective. Their reflections were also important in alerting instructors to any flaws or weaknesses in the delivery of the CURE.

Providing an equal opportunity, an equitable experience, and inclusion for all students met the goals for infusing a CURE into an existing course in the applied sciences. This experience did require careful planning with great attention to detail, but in the end, it provided all students an opportunity to "spread their wings" and work on a research protocol at every point along the way, while they were learning to be a contributing member of a research team.

\section{REFERENCES}

1. Auchincloss, L.C., Laursen, S., Branchaw, J., Eagan, K., Graham, M., Hanauer, D. Assessment of Course-Based Undergraduate Research Experiences: A Meeting Report. CBE-Life Sciences Education. 2004;13: 29-40. doi: 10.1187/cbe.14-01-0004 PMID: 24591501

2. Shortlidge, E., Bangera, G., and Brownell, S. Each to Their Own CURE: Faculty Who Teach Course-Based Undergraduate Research Experiences Report Why You Too Should Teach a CURE. Journal of Microbiology and Biology Education. 2017 May 26; 18(2): 18.2.29. doi: https://doi.org/10.1128/jmbe.v1812.1260. PMID: 28656071 
3. Shaffer, C., Alvarez, C., Bednarski, A., Dunbar, D., Goodman, A., Reinke, C., et al. A Course-Based Research Experience: How Benefits Change with Increased Investment in Instructional Time. CBE Life Sciences Education. 2014; 13: 111-130. doi: 10.1187/cbe-13-08-0152 PMID: 24591510

4. Kowalski, J.R., Hoops, G.C., and Johnson, R.J. Implementation of a Collaborative Series of Classroom-Based Undergraduate Research Experiences Spanning Chemical Biology, Biochemistry, and Neurobiology. CBE Life Sciences Education. 2016; 15: 1-17. doi: 10.1187/cbe.16-02-0089 PMID: 27810870

5. Genné-Bacon, E.A., and Bascom-Slack, C.A. The PARE Project: A Short Course-Based Research Project for National Surveillance of Antibiotic-Resistant Microbes in Environmental Samples. Journal of Microbiology \& Biology Education. 2018;19(3): 1-7. doi: https://doi.org/10.1128//mbe.v19i3.1603 PMID: 30377474

6. Mader, C.M., Beck, C.W., Grillo, W.H., Hollowell, G.P., Hennington, B.S., Staub, N.L., et al. Multi-Institutional, Multidisciplinary Study of the Impact of Course-Based Research Experiences. Journal of Microbiology \& Biology Education. 2017;18(2): 1-11. doi: https://doi.org/10.1128/imbd.v18i2.1317 PMID: 28861141

7. Ballen,C.J., Blum, J., Brownell, S., Hebert, S., Hewlett, J., Klein, J., et al. A Call to Develop Course-Based Undergraduate Research Experiences (CURES) for Nonmajors Courses. CBE Life Sciences Education. 2017; 16: 1-6. doi: 10.1187/cbe.1612-0352 PMID: 28450449

8. Heim, A.B. and Holt, E. A. Benefits and Challenges of Instructing Introductory Biology Course-Based Undergraduate Research Experiences (CUREs) as Perceived by Graduate Teaching Assistants. CBE Life Sciences Education. 2019; 18: 112. doi: 10.1187/cbe.18-09-0193 PMID: 31469618

9. Diaz-Martinez, L., Fisher, G., Esparza, D., Bhatt, J., D’Arcy, C., Apodaca, J., et al. Recommendations for Effective Integration of Ethics and Responsible Conduct of Research (E/RCR) Education into Course-Based Undergraduate Research Experiences: A Meeting Report. CBE Life Sciences Education. 2019; June (18): 1-10. doi: 10.1187/cbe.18-10020 PMID: 31120396

10. Cooper, K.M. and Brownell, S.E. Developing Course-Based Research Experiences in Discipline-Based Education Research: Lessons Learned and Recommendations. Journal of Microbiology \& Biology Education. 2018; 19(2): 1-6. doi: https://doi.org/10.1128/jmbe.v19i2.1567 PMID: 30197730

11. Wolkow, T., Jenkins, J., Durrenberger, L., Swanson-Hoyle, K., and Hines, L. One Early Course-Based Undergraduate Research Experience Produces Sustainable Knowledge Gains, but only Transient Perception Gains. Journal of Microbiology \& Biology Education. 2019; 20(2): 1-14. doi: https://doi.org/10.1128/jmbe.v20i2.1679 PMID: 30316688

12. Irby, S.M., Pelaez, N.J., and Anderson, T.R. How to Identify the Research Abilities That Instructors Anticipate Students Will Develop in a Biochemistry Course-Based Undergraduate Research Experience (CURE). CBE Life Sciences Education. 2018; 17: 1-14. doi: 10.1187/cbe.17-12-0250 PMID: 29749847

13. Olimpo, J.T., Fisher, G.R., and DeChenne-Peters, S. Development and Evaluation of the Tigriopus Course-Based Undergraduate Research Experience: Impacts on Students' Content Knowledge, Attitudes, and Motivation in a Majors Introductory Biology Course. CBE Life Sciences Education. 2016; 15: 1-15. doi: 10.1187/cbe.15-11-0228 PMID: 27909022 